\title{
前立腺重量と食事，喫煙，飲酒の関係についての疫学的検討
}

\author{
京都府立医科大学泌尿器科学教室（主任：渡辺 泱教授) \\ 温 井 雅 紀
}

\section{EPIDEMIOLOGICAL STUDY ON DIET, SMOKING AND ALCOHOL DRINKING IN THE RELATIONSHIP TO PROSTATIC WEIGHT}

\author{
Masanori Nukui \\ Department of Urology, Kyoto Prefectural University of Medicine
}

(Background) There have been no epidemiological studies on the relationship between the prostatic weight and blood examination data. This study was carried out to evaluate this relationship.

(Subjects and Methods) Blood examination ( $\beta$-carotene, GOT, GPT, total cholesterol, etc.) and measurement of the prostatic weight were performed in 432 subjects aged 50 years or more of a town in Japan, and the possible relationship between blood analysis data and the prostatic weight was evaluated. The prostates were examined by transrectal ultrasonography (TRUS) and classified into the normal prostate and benign prostatic hypertrophy (BPH). The prostatic weight was measured by Watanabe's method based on TRUS images. In addition, the possible association between the prostatic weight and smoking, drinking, height, body weight, or age was evaluated.

(Results) Analysis by the logistic procedure and the general linear models procedure showed a significant positive correlation between the normal prostatic weight and $\beta$-carotene, height, as well as body weight and a significant negative correlation between the normal prostatic weight and smoking. Comparison between subjects with the normal prostate and those with BPH suggested that serum $\beta$-carotene is a significant positive risk for $\mathrm{BPH}$, and HDL-cholesterol, drinking, and smoking are negatie risks by logistic procedure analysis.

(Conclusion) It was thought that serum $\beta$-carotene and smoking are associated with the development of $\mathrm{BPH}$.

Key words: prostatic weight, blood examination, data, epidemiology

要旨：(背景)前立腺重量と血液デー夕との関係に関する疫学的検討は, 今までに行われておらず，この 研究はそれらの関係を調べるために行われた。

(対象と方法) 北海道 Y 町において1988年から1990年に行った前立腺集団検診受診者のうち，50歳以 上の前立腺癌を除いた 432 名を対象とした。血液検査 ( $\beta$-カロチン, 総タンパク, 総コレステロール, GOT, GPT など) と前立腺重量測定を行い, 前立腺重量と血液データとの関係を検討した. 前立腺は経直腸的 超音波断層像（TRUS）にて検査し，正常前立腺と前立腺肥大症（BPH）に分類した。前立腺重量は渡 辺の方法に従い, TRUSより計測した。 また，前立腺重量と喫煙・飲酒・身長・体重・年齢との関係も 検討した。

(結果) SAS の logistic procedure と general linear models procedureによる分析では，正常前立 腺重量と $\beta$-カロチン・身長・体重が有意な正の相関を示し, 喫煙と正常前立腺重量は有意な負の相関を 示した。前立腺肥大症症例と正常例を比較すると, 血清 $\beta$-カロチンは肥大症の有意な positive risk であ 
り，HDL-コレステロール，飲酒および喫煙は negative riskであった。

（結論）血清 $\beta$-カロチンと喫煙は前立腺肥大の形成に影響を与えていると考えられた.

キーワード：前立腺重量, 血液デー夕, 疫学

\section{緒言}

前立腺疾患は人口の高齢化にともない増加の一途を たどっており，中高年男性の重要疾患のひとつとなっ ている。前立腺癌は, 欧米では男性悪性腫瘍死亡原因 の 1 位か 2 位を占めているが，日本では下位に属して いる。しかし我が国における前立腺癌による死亡率の 増加は著しく, その増加率は各種㤟性腫瘍中第 1 位, 世界各国間の比較でもメキシコについで第 2 位であ り, 今後はさらに急増するものと想像されている ${ }^{11}$. 同 様に前立腺肥大症も，人口の高齢化とともに今後も増 加するものと考えられる.

当教室では, 子防医学の立場より経直腸的超音波断 層法をスクリーニングとして用いた前立腺集団検診を 1976年より全国各地で行い，多数の前立腺疾患の早期 発見に貢献してきた。 また, 名古屋大学医学部予防医 学教室と共同で, 北海道 Y 町において1988年より前立 腺集団検診を行っており，同時に癌予防に関し注目さ れている $\beta$-カロチンをはじめ, 肝機能・腎機能・脂質 などの血液検査, および食習慣について問診調査を施 行してきた. 本論文では, これらの結果をもとに疫学 的検討を行った。

\section{対象および方法}

北海道 Y 町は, 人口約 20,000 人の農業・酪農・漁業 の町である。ここで1988年より1990年の 3 年間に前立 腺集団検診を受診した50歳以上の男性のうち，前立腺 重量計測が可能で, 重複を除いた受診者は436名であっ た。これらの受診者の診断結果は正常者 373 名, 前立腺 肥大症 59 名, 前立腺癌 4 名であったが, 前立腺癌 4 名 を除く432名を検討の対象とした.ここでいう前立腺肥 大症は, 経直腸的超音波断層像上り日本超音波医学会 の診断基準 ${ }^{2}$ に準拠して判定した.

前立腺重量の算出は, 渡辺らの方法 ${ }^{3}$ に従い, $5 \mathrm{~mm}$ ごとの前立腺超音波断層像の各前立腺断面積の和に 0.5 を乗じた前立腺推定容量を, 前立腺の比重はほぼ 1.0 なので, 前立腺重量に読みかえた。この方法に従え ば，推定重量の誤差は $5 \%$ 以内である ${ }^{3)}$.

血液検査は, 空腹時に採血し, $\beta$-カロチン・総タン パク・アルブミン・GOT・GPT・BUN・クレアチニ ン・総コレステロール・HDL-コレステロール・中性脂 肪を，それぞれ測定した. $\beta$-カロチン $(\mu \mathrm{g} / \mathrm{dl})$ の測定 ${ }^{4)}$
は, 一80度に保存した血清を HPLC 法にて処理し， Miller's 法を利用して行った。

また，問診により飲酒・喫煙習慣についても調査し， 背景因子として，年齢・身長・体重も検討に加えた. それぞれの結果と前立腺重量との関連を検討した。統 計処理はSASによる GLM (General Linear Model), logistic procedure を用いた単変量および多変量解析 を利用した. $\mathrm{p} \leqq 0.05$ の場合を統計学的に有意, $0.05<$ $\mathrm{p} \leqq 0.10$ 場合を『傾向あり』と判定した.

\section{1）年齢構成}

結果

対象者の年齢分布は, Fig. 1 に示すごとく50歳代か ら80歳代で, 平均 62.0 歳であった. 斜線の部分は前立 腺肥大症である。

肥大症の割合は，50歳代 $5.8 \% ， 60$ 歳代 $11.6 \%, 70$ 歳

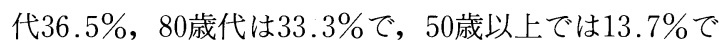
あった。

2) 前立腺重量別症例数

前立腺重量の分布は, $10 \mathrm{~g}$ ごとに分けると Fig. 2 に 示すごとくであり, 斜線の部分は前立腺肥大症である. 全体に対し肥大症の占める割合は $13.7 \%$ で，20g 以上 のうちでは $25.8 \%$ であった。正常前立腺重量は平均 $19.7 \mathrm{~g}$, 肥大症では平均 $38.2 \mathrm{~g}$ であった。

3）前立腺正常例における検討

(1) Logistic procedureによる検討

Fig. 1 Age distribution of the cases

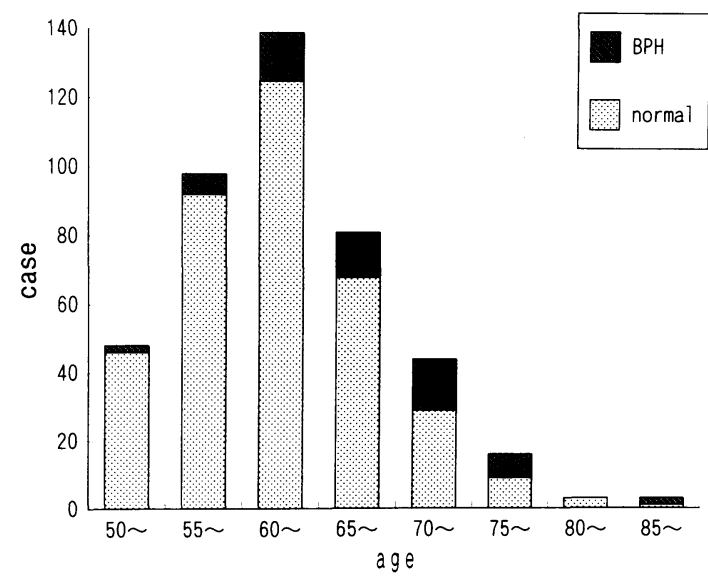


Fig. 2 Weight distribution of the prostates

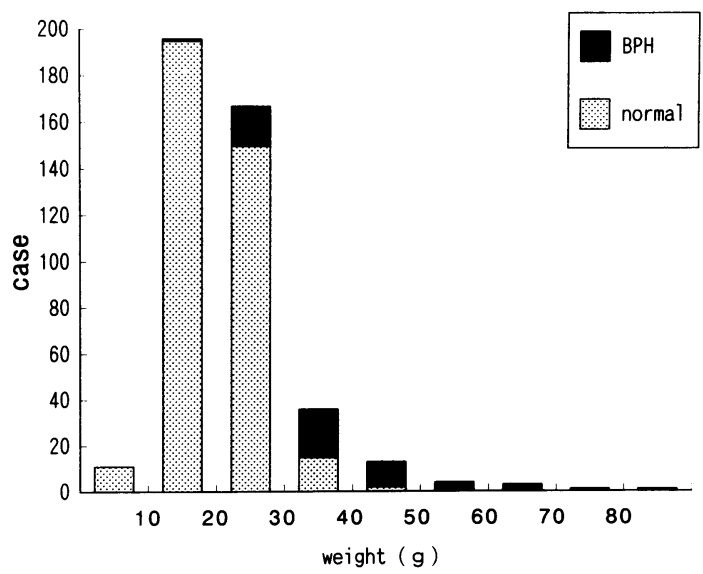

Table 1 Analysis by logistic procedure on the prostatic weight in normal subjects

\begin{tabular}{l|c|l}
\hline & Odds ratio & p-value \\
\hline Total protein & 1.57 & $0.079^{*}$ \\
Albumin & 1.68 & 0.227 \\
GOT & 1.02 & 0.257 \\
GPT & 1.01 & 0.598 \\
BUN & 1.06 & $0.024^{* *}$ \\
Creatinine & 2.99 & $0.074^{*}$ \\
Total cholesterol & 1.01 & 0.111 \\
HDL-cholesterol & 1.00 & 0.826 \\
Triglyceride & 1.00 & 0.431 \\
$\beta$-carotene & 1.01 & $0.027^{* *}$ \\
Age & 0.99 & 0.441 \\
Height & 1.11 & $0.0001^{* * *}$ \\
Weight & 1.03 & $0.029^{* *}$ \\
Alcohol drinking & 1.00 & 0.991 \\
Smoking & 0.47 & $0.011^{* *}$ \\
\hline
\end{tabular}

${ }^{*} 0.05<\mathrm{p} \leqq 0.1 \quad{ }^{* *} 0.01<\mathrm{p} \leqq 0.05 \quad * * * \mathrm{p} \leqq 0.01$

正常前立腺重量を，小さいものより $75 \%$ を超える群 とそうでないものの 2 群に分けると, その境界值は $22.9 \mathrm{~g}$ で, $22.9 \mathrm{~g}$ 以下 281 症例, $23.0 \mathrm{~g}$ 以上 91 症例であっ た。この 2 群間で odds ratio を logistic procedure を 用い算出した．前立腺重量を増加させる要因を positive risk と考えれば，喫煙は有意な negative risk で， odds ratio は0.47 ( $\mathrm{p}=0.011)$ であった. positive risk は, 血液検査では $\mathrm{BUN}$ ・ $\beta$-カロチンが有意で, odds ratio はそれぞれ1.06，1.01，そして身長・体重にも有 意差を認め, odds ratio はそれぞれ1.11，1.03であっ た。そのほか, 総タンパクおよびクレアチニンに positive risk の傾向があった (Table 1).
Table 2 Analysis by general linear model procedure on the prostatic weight in normal subjects (simple regression analysis)

\begin{tabular}{l|c|l}
\hline & Estimate & p-value \\
\hline$\beta$-carotene & 0.037 & $0.006^{* * *}$ \\
Total cholesterol & 0.022 & $0.013^{* *}$ \\
Height & 0.275 & $0.0001^{* * *}$ \\
Weight & 0.111 & $0.0001^{* * *}$ \\
Age & -0.047 & 0.321 \\
\hline${ }^{* *} 0.01<\mathrm{p} \leqq 0.05 \quad{ }^{* * *} \mathrm{p} \leqq 0.01$
\end{tabular}

Table 3 Correlations between the prostatic weight in normal subjects and smoking or alcohol drinking

\begin{tabular}{l|c|c}
\hline & $\begin{array}{c}\text { Mean prostatic } \\
\text { weight }(\mathrm{g})\end{array}$ & p-value \\
\hline Current smoker & 18.8 & - \\
Ex-smoker & 19.2 & 0.574 \\
Non-smoker & 21.1 & $0.004^{* * *}$ \\
Current drinker & 20.2 & - \\
Ex-drinker & 19.4 & 0.437 \\
Non-drinker & 19.6 & 0.446 \\
\hline
\end{tabular}

${ }^{* * *} \mathrm{p} \leqq 0.01$

(2) General linear model による検討

単変量解析を用いて正常前立腺重量と血液検査結果 を分析すると， $\beta$-カロチン・総コレステロールが正の 相関を示した。身長・体重・年齢との関係では身長・ 体重が正の相関を示し,特に身長に強い相関を認めた。 年齢と正常前立腺重量とは有意な相関を認めなかった (Table 2).

飲酒・喫煙と正常前立腺重量の関係を検討すると, 喫煙するものとしないもので明らかな有意差を認め $(\mathrm{p}=0.004)$ ，喫煙するものがしないものに比し平均值 で2g 以上小さかった。また，喫煙者・過去の喫煙者・ 非喫煙者の前立腺重量の間に, dose-response を認め た. 飲酒に関しては, 有意差を認めなかった（Table 3).

Table 2,3 の検討項目を多変量解析により検討した が，正常前立腺重量はやはり喫煙・ $\beta$-カロチン・総コ レステロール・身長と有意に相関を示した (Table 4).

4）前立腺肥大症症例における検討

前立腺肥大症症例の前立腺重量と血液検査結果 - 身 長・体重・年齢との関係を検討したが，血液検査結果 と重量との関係は認めることはできず, 年齢でのみ相 関 $(\mathrm{p} \leqq 0.05)$ を認め, 高齢であるほど肥大症の前立腺 
Table 4 Analysis by general linear model procedure on the prostatic weight in normal subjects (multiple regression analysis)

\begin{tabular}{l|l}
\hline & p-value \\
\hline$\beta$-carotene & $0.036^{* *}$ \\
Total cholesterol & $0.032^{* *}$ \\
Height & $0.0001^{* * *}$ \\
Weight & 0.691 \\
Age & 0.621 \\
Smoking & $0.014^{* *}$ \\
Alcohol drinking & 0.600 \\
\hline$* * 0.01<p \leq 0.05 * * *$ &
\end{tabular}

${ }^{* *} 0.01<\mathrm{p} \leqq 0.05 \quad{ }^{* * *} \mathrm{p} \leqq 0.01$

Table 5 Relative risk of $\mathrm{BPH}$ related to blood examination data, smoking and alcohol drinking

\begin{tabular}{l|c|l}
\hline & Odds ratio & p-value \\
\hline Total protein & 1.56 & 0.122 \\
Albumin & 0.41 & $0.067^{*}$ \\
GOT & 0.98 & 0.399 \\
GPT & 0.99 & 0.391 \\
BUN & 1.02 & 0.479 \\
Creatinine & 2.53 & 0.182 \\
Total cholesterol & 1.00 & 0.287 \\
HDL-cholesterol & 0.98 & $0.058^{*}$ \\
Triglyceride & 1.00 & 0.551 \\
$\beta$-carotene & 1.02 & $0.0001^{* * *}$ \\
Height & 0.99 & 0.616 \\
Weight & 1.01 & 0.525 \\
Age & 1.13 & $0.0001^{* * *}$ \\
Smoking & 0.39 & $0.007^{* * *}$ \\
Alcohol drinking & 0.36 & $0.001^{* * *}$ \\
\hline
\end{tabular}

${ }^{*} 0.05<\mathrm{p} \leqq 0.1 \quad{ }^{* *} 0.01<\mathrm{p} \leqq 0.05 \quad{ }^{* * *} \mathrm{p} \leqq 0.01$

\section{重量は大きかった。}

5）前立腺正常例と肥大症症例の比較

Logistic procedure を用い正常例と肥大症症例を比 較した。単変量解析では, $\beta$-カロチン・年齢は前立腺 肥大症の有意な positive risk で, odds ratio はそれぞ れ1.02 ( $\mathrm{p}=0.0001), 1.13(\mathrm{p}=0.0001)$ であった。飲 酒・喫煙は肥大症の有意な negative risk で, odds ratio はそれぞれ0.36 $(\mathrm{p}=0.001) ， 0.39(\mathrm{p}=0.007)$ であった.アルブミンと HDL-コレステロールは, negative risk の傾向を示した (Table 5). 多変量解析で も $\beta$-カロチン・年齢は肥大症の有意な positive risk で あり，飲酒・喫煙は有意差は消失したが negative risk の傾向を示した. HDL-コレステロールは肥大症の有 意な negative risk であったが,アルブミンには有意差
Table 6 Relative risk of $\mathrm{BPH}$ related to blood examination data, smoking and alcohol drinking (multiple regression analysis)

\begin{tabular}{l|c|l}
\hline & Odds ratio & p-value \\
\hline Albumin & 0.739 & 0.594 \\
HDL-cholesterol & 0.973 & $0.021^{* *}$ \\
$\beta$-carotene & 1.018 & $0.002^{* * *}$ \\
Age & 1.135 & $0.0001^{* * *}$ \\
Smoking & 0.474 & $0.062^{*}$ \\
Alcohol drinking & 0.540 & $0.084^{*}$ \\
\hline$* 0.05<0^{* * 1 * 0.01}$
\end{tabular}

を認めなかった（Table 6).

\section{考察}

私たちの教室では，1976年に「前立腺癌の高危険度 群と予防癌学をめぐる workshop $\rfloor^{5}$ を京都で開催以 後, 前立腺に関する疫学的研究を前立腺集団検診とと もに行ってきた。その結果を, 三品ら ${ }^{6}$ が前立腺癌, 荒 木 ${ }^{7)}$ が前立腺肥大症について, さらに戎井 ${ }^{8}$ が前立腺重 量と食・性生活について報告した。それらの研究結果 によると, 食生活については, 前立腺癌では, 魚介類 をあまりとらず，緑黄色野菜の摄取が少なく，香辛料 や塩っぱいものを好む人, 前立腺肥大症では, 毎日肉 類を食べ，牛乳を飲み，緑黄色野菜や漬物の摂取が少 ない人だという。すなわち，ともに西欧型食生活が特 徵とされた。また前立腺重量に関しては, 魚介類の捸 取と米食など，日本型食生活が前立腺重量に対し抑制 的であるとする結果であった。これまでにも前立腺疾 患と栄養・代謝にかかわる血液デー夕の検討 ${ }^{9}$ は行わ れてはいるが, 今回の検討は, これらの疫学的研究結 果を踏まえ, 主に前立腺重量と血液デー夕の関係から, これまでの結果をさらに樑く検証するものである.

食習慣により当然各種血清濃度は変化すると考元ら れる. 緑黄色野菜を頻繁に摄取すると, 血漿 $\beta$-カロチ ン濃度が上昇することが知られており ${ }^{10)}, \beta$-カロチン を緑黄色野菜摂取の指標としてもよいと考えた。そし て, 血清 $\beta$-カロチン濃度は飲酒・喫煙により低下し, 高齢男性では上昇するとされており ${ }^{11)}$, その他, 中性脂 肪・コレステロールなども年齢・喫煙などの影響を受 けるため,これらの影響に注意して検討する必要が あった。

私たちの教室は, 京都府を中心に滋賀県, 遠くは宮 崎県, 青森県, 秋田県などで前立腺集団検診を行って きたが, それらの平均として, 55歳以上の検診受診者 男性の約 $18 \%$ に前立腺肥大症が存在するという結果を 
得ている ${ }^{12)}$.しかし, 北海道 Y 町だけに限れば，前立 腺肥大症は50歳以上で $13.7 \%$ であり，この地域は肥大 症の少ない地域と考えられた。また，正常前立腺重量 は19.7gであったが,これはほぼ平均的であると考え られた

正常前立腺重量の検討では, logistic procedure・ general linear model による分析ともに $\beta$-カロチン・ 身長が有意な positive risk で正の相関があり，喫煙が negative risk で負の相関があった. Positive risk とい うと何か悪い意味に聞こえるが，これは言葉を換えれ ば前立腺重量促進要因ということである.これに対し， negative risk はその促進傾向を妨げる文字どうり negative な要因と考えるべきであろう.

General linear model では, 正常前立腺重量は総コ レステロールとも正の相関を認めたが，これは $\beta$-カロ チンとコレステロールの担体タンパクが類似している ためと考えられる(13)とともに，ステロイドとしての性 ホルモンの生合成との因果関係をも考えさせる。 Logistic procedure では BUN も positive risk であっ たが，高タンパク食のような食事性要因と関係がある のかもしれない. 総タンパクも有意ではないが positive risk の傾向があり，一般にタンパク摂取が多いと 前立腺は大きくなると考えてよいようである.

$\beta$-カロチンには, 抗酸化能や免疫増強作用による癌 抑制効果が推測されているが ${ }^{13)}$, ビタミン A としての

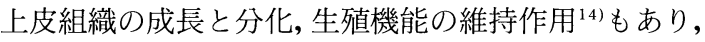
この作用が前立腺重量に影響している可能性も考えら れた。

喫煙と正常前立腺重量との関係では，喫煙の odds ratio は 0.47 と 2 倍以上の negative riskであった. General linear model による解析結果でも喫煙経験と 前立腺重量の間には dose-response があり,さらに後 述するごとく前立腺肥大症においても喫煙はnegative risk であることを考えあわせると，喫煙は前立腺 の重量促進を妨げる最重要な要因であることは明らか で, 本研究で得られた成果の内で最も意義深いもので ある.

以上の結果からは，正常前立腺重量は身長の高い人 ほど大きく, 喫煙により小さくなり, 血清 $\beta$-カロチン 濃度の高い人,すなわち緑黄色野菜を多く摂取する人, さらなる可能性として高タンパク・高コレステロール 食を好む人は大きくなる傾向があるといえる.

前立腺正常例と前立腺肥大症症例を比較すると，肥 大症症例で年齢が positive risk であることは当然と
思われるが, さらに血清 $\beta$-カロチンも positive risk で あった。これは正常前立腺と同様に $\beta$-カロチンが，前 立腺上皮の形成に促進的に働き, 結果的に肥大症の発 生に関与しているとも考えられる。

また，前立腺肥大症の発生には，加齢に伴う estrogen/androgen 比の増大が関係していると考えら れてきているが, 野菜は腸内細菌により弱い estrogen 作用を持つ物質を形成する ${ }^{15)}$ とされ，ホルモン的側面 でも緑黄色野菜摂取は肥大症に関与しているのかも知 れない.

HDL-コレステロールは西洋人に比べ日本人は高値 を示し, 肥大症の negative risk として理解しやすく, またエストロゲン・アンドロゲンの影響を受けるとさ れていることを考え合わせると的，HDL-コレステ ロールも肥大症発生に関わるひとつの因子と考えられ ないことはない.

飲酒・喫煙習慣に関しては，肥大症症例には飲酒・ 契煙をしない人が多いという結果であった。これにつ いてはすでに荒木7)の検討でも, 統計的な有意差はな いものの同じ結果が示されていた。

前立腺疾患の疫学的研究は, 国内・国外を問わず主 に前立腺癌について行われている。これまで, 一定し た見解とはいえないものの, 食生活に限ると, 前立腺 癌の negative risk として $\beta$-カロチンを含む緑黄色野 菜 $^{17) ~ 20)}$, 米飯・豆腐 ${ }^{21)}$, positive risk としては脂肪・ 動物性タンパク 1921122)が挙げられている.

従来, 喫煙・飲酒は前立腺癌の有意な risk として報 告はされていなかったが, 最近の大規模コホート研究 では，喫煙は positive risk とされている23.

前立腺肥大症に関する疫学的研究報告は, 前立腺癌 に比べると少ないが，喫煙に関しては多数の報告で negative risk と考えられている22). 前述のごとく, 今 回の結果で最も意義深い成績は喫煙と前立腺重量促進 阻害との関係であり, これは従来の報告ともよく一致 していた。

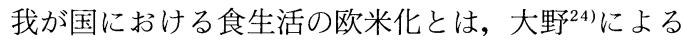
と，特に1975年頃までの動物性タンパク・脂肪・動物 性脂肪の摂取増と炭水化物摂取の漸減であるとされて いるが，この間総エネルギー量はほとんど変化してい ない．また，魚介類摂取もあまり変化していない。脂 肪・タンパク質摂取量を日米で比較すると ${ }^{24)}$ ，脂肪は， 1940年代以前は米国は日本の約 9 倍であり，1975年頃 までに約 3 倍とかなり近づいたもののまだ日本より多 く，またタンパク質は，同様に1.7倍が1.2倍になった 
だけで，差はほとんどなくなってきた。しかし，魚介 類の摂取は，米国ではきわめて少ない。これら食生活 の状況を疫学的デー夕と考え合わせると,やはり動物 性タンパク・動物性脂肪の摂取増は一般に前立腺疾患 の positive risk と考えやすい.

緑黄色野菜に関しては, 日本では1975年以後その摂 取量は次第に増加している ${ }^{25)}$. 緑黄色野菜の摂取は前 立腺癌の negative risk とされているが, 近年の前立腺 癌増加の現状にはその効果は, 反映されていないよう である。

前立腺重量に言及した疫学的検討は, 世界的にほと んどなされておらず，したがって今回の結果を他と比 較することは難しかった. しかし, 正常前立腺の重量 は，契煙，そして $\beta$-カロチンの影響を受けていること はほぼ確実であろう。このことが実際に前立腺疾患に いかに関係するかは今後の検討を待つ必要があるが, 今回の結果は, 前立腺疾患と喫煙・緑黄色野菜摂取と の因果関係を解明する，ひとつの手がかりになるので はないかと考える。

\section{結 語}

1）北海道 $Y$ 町における前立腺集団検診において, 前立腺重量と血液データ・飲酒・喫煙習慣などとの関 連を検討した。

2）正常前立腺重量の促進に対しては, 身長は有意な positive risk, 喫煙は有意の negative risk, 血清 $\beta$-力 ロチン濃度は有意の positive risk であった。

3）前立腺肥大症に対しては, 飲酒および喫煙は negative risk の傾向を認め, 血清 $\beta$-カロチンは有意な positive risk であった.

本稿を終えるにあたり，ご指導ご校閲をいただいた渡辺 泱教授，実際に集団検診にご尽力くださった中川修一講師 をはじめとする京都府立医科大学泌尿器科学教室 - 名古屋 大学医学部公衆衛生学教室の教室員各位, 北海道 $\mathrm{Y}$ 町の皆 様, ならびに統計処理にご協力いただいた愛知医科大学公 衆衛生学教室鈴木貞夫講師に深謝する。

なお, 本研究の一部は, 文部省がん特別研究「コホート研 究による発がん要因の評価に関する研究 (青木班)」助成金 の援助によって行なわれた。

\section{文献}

1）黑石哲生：前立腺がん死亡の記述疫学特性と死亡 動向の将来予測. 平成 6 年度渡辺班報告書, 1995 .

2) 日本超音波医学会医用超音波診断基準に関する委 員会: 泌尿器科の超音波診断基準案公示のお知ら せ。超音波医学，12，178-181，1985.

3）渡辺 泱, 猪狩大陸, 海法裕男, 棚橋善克, 原田一
哉, 斉藤雅人：超音波断層法による前立腺計測。西 日泌尿，37，222-232， 1975.

4) Ito, Y., Sasaki, R., Minohara, M., Ohtani, M. and Aoki, K.: Quantitation of serum carotenoid concentrations in healthy inhabitants by high-performance liquid chromatography. Clin. Chem. Acta, 169, 197-208, 1987.

5) 渡辺 泱, 三品輝男, 平山 雄, 加藤寛夫, 熊本悦 明, 吉田 修: 前立腺癌の高危険度群と予防癌学 をめぐる workshop. 泌尿紀要，24，129-144， 1978.

6) 三品輝男, 渡辺 決, 荒木博孝, 都田慶一, 藤原光 文, 小林徳朗, 前川幹雄：前立腺癌の疫学的研究 (第 1 報) 一面接法による前立腺癌高危険度群の検 討一. 日泌尿会誌，72，1256-1279，1981.

7）荒木博孝：前立腺肥大症の疫学的研究. 日泌尿会 誌, 72, 1477-1491， 1981.

8）戎井浩二：前立腺重量と食生活 - 性生活との関係 に関する疫学的研究. 京府医大誌, 101, 805-816, 1992.

9) Boyd, E.M. and Berry, N.E.: Prostatic hypertrophy as a part of a generalized metabolic disease. Evidence of the presense of a lipopenia. J. Urol., 41, 406-412, 1939.

10) Suzuki, S., Sasaki, R., Ito, Y., Hamajima, N., Shibata, A., Tamakoshi, A., Ohtani, M. and Aoki, K.: Changes in serum concentrations of $\beta$-carotene and changes in the dietary intake frequency of green-yellow vegetables among healthy male inhabitants of Japan. Jpn. J. Cancer Res., 81, 463-469, 1990.

11) Aoki, K., Ito, Y., Sasaki, R., Ohtani, M., Hamajima, N. and Asano, A.: Smoking, alcohol drinking and serum carotenoid levels. Jpn. J. Cancer Res., 78, 1049-1056, 1987.

12）渡辺 泱：我国に扔ける前立腺集団健診の現状. 日本医事新報, 3600，27-34，1993。

13）伊藤宜則, 家田ま仂み, 新谷良英, 浜松昭雄, 小森 義隆, 水谷直美：健常成人における血清カロチ， イド値と末梢リンパ球サブセット分布量との関連 性. ビタミン，69，297-308，1995.

14）日本ビタミン学会編：ビタミン学 I 脂溶性ビタミ ン. 東京化学同人, $\mathrm{p} 17-98,1980$.

15）杉村芳樹：前立腺肥大症自然史の基礎：前立腺增 殖に打ける生物学的特性. 日泌尿会誌, 87, 721739, 1996.

16）Thompson, G.R.：血墏脂質とリポ蛋白. 高脂血 㢡，初版，p1-19,萬有製薬 K.K., 1991.

17）平山 雄: 前立腺ガンの疫学. 予防ガン学一その 新しい展開一, p148-157,ライフサイエンス, 東 京, 1987.

18) Ohno, Y., Yosida, O., Oishi, K., Okada, K., 
Yamabe, H. and Schroeder, F.H.: Dietary $\beta$-carotene and cancer of the prostate: A casecontrol study in kyto, Jpn. Cancer Res., 48, 1331 $-1336,1988$.

19) Mettlin, C., Selenskas, S., Natarajan, N. and Huben, R. : Beta-carotene and animal fats and their relationship to prostate cancer risk. Cancer, 64, 605-612, 1989.

20) Oishi, K., Okada, K., Yoshida, O., Yamabe, H., Ohno, Y., Hayes, R.B. and Schroeder, F.H.: A case-control study of prostatic cancer with reference to dietary habits. Prostate, 12, 179190, 1988.

21) Armstrong, B. and Doll, R.: Environmental factors and cancer incidence and mortality in different countries, with special reference to dietary practice. Int. J. Cancer, 15, 617-631, 1975.

22) Rotkin, I.D.: Studies in the epidemiology of prostatic cancer: Expanded sampling. Cancer Treat. Rep., 61, 173-180, 1977.

23) Matzkin, H. and Soloway, M.S.: Cigarette smoking: A review of possible associations with benign prostatic hyperplasia and prostate cancer. Prostate, 22, 277-290, 1993.

24）大野良之：脂肪摂取と循環器疾患およびがんに関 する疫学的考察. 日循協誌，24，34-39，1989.

25）厚生省保健医療局健康増進栄養課編：平成 6 年度 版国民栄養の現状. p29-56,第一出版, 東京, 1994. （1996年12月24日受付，1997年 6 月 9 日受理） 